\title{
Smartphone: Bagaimana Pengaruh terhadap Motivasi Belajar Siswa Sekolah Dasar?
}

\author{
Khairul Sani ${ }^{1}$, Adi Apriadi Adiansha ${ }^{2 *}$ \\ 1,2Prodi PGSD, STKIP Taman Siswa Bima \\ Email: 1iruelonline@gmail.com, ${ }^{2}$ adiapriadiadiansyah@gmail.com
}

\begin{abstract}
The use of smartphones can be detrimental to improving the quality of students, especially in elementary schools, this is influenced by excessive smartphone use. The purpose of this study was to explain the effect of smartphones on student motivation in elementary schools in Bolo District. This research was conducted at the Bolo District Elementary School. The sample used was 84 students. This research is a quantitative approach using a survey method. This research has stages: observation of the research location, preparation of questionnaires, distribution of questionnaires, validity testing, data collection, processing of research results, analysis of research results, and discussion. The results showed that the effect of smartphones on student motivation in elementary school even though it is in the low category. Suggestions as recommendations: students do not use smartphones excessively both at school and at home. Parents and teachers always supervise children, especially using smartphones every day because the effect of smartphones on student learning motivation is very low.
\end{abstract}

Keywords: Smartphone, Motivation

Abstrak. Penggunaan smartphone dapat merugikan terhadap peningkatan mutu siswa terutama disekolah dasar, hal tersebut dipengaruhi penggunaan smartphone yang berlebihan. Tujuan dari penelitian ini adalah untuk menjelaskan pengaruh smartphone terhadap motivasi belajar siswa di sekolah dasar di Kecamatan Bolo. Penelitian ini dilakukan di Sekolah Dasar Kecamatan Bolo. Sampel yang digunakan adalah 84 siswa. Penelitian ini adalah pendekatan kuantitatif dengan menggunakan metode survei. Penelitian ini memiliki tahapan: pengamatan lokasi penelitian, penyusunan kuesioner, distribusi kuesioner, pengujian validitas, pengumpulan data, pengolahanhasil penelitian, analisis hasil penelitian, dan diskusi. Hasil penelitian menunjukkan bahwa pengaruh smartphone terhadap motivasi belajar siswa di SD meskipun berada dalam kategori rendah. Saran sebagai rekomendasi: siswa tidak menggunakan smartphone yang berlebihan baik di sekolah maupundi rumah. Orang tua dan guru selalu mengawasi anak-anak terutama menggunakan smartphone setiap hari karena efek smartphone pada motivasi belajar siswa sangat rendah.

Kata Kunci: Smartphone, Motivasi

\section{PENDAHULUAN}

Dalam era terakhir ini, teknologi informasi dan komunikasi mengalami perkembagan pesat terutama dalam penggunakan smartphone (Bağcı \& Pekşen, 2018; Criollo \& Luján-Mora, 2018; Daltio et al., 2018; Migdalski, 2017; Nicolaou et al., 2019; Nyasulu \& Dominic Chawinga, 2019; PedreroEsteban et al., 2019; Susilawati \& Adiansha, 2018; et al., 2019; Yildiz \& Alkan, 2019). Akhir-akhir ini penggunaan smartphone telah mengubah kehidupan sehari-hari lebih dari teknologi lainnya, karena smartphone memberikan fasilitas yang cukup banyak perangkatnya. Dalam satu alat, smartphone memasukkan semua kemampuan (1) pemutar musik, (2) kamera, (3) televisi, (4) Sistem Pemosisian Global, (5) kendali jarak jauh, (6) game, (7) komputer pribadi, dan (8) bahkan mengganti router dengan menjadi hotspot wifi. Perangkat yang kuat mungkin memiliki jumlah aplikasi yang tak terhitung yang dapat mempengaruhi pendidikan modern di Indonesia dan di seluruh dunia.

Namun faktanya yang terjadi bahwa penggunaan smartphone dapat mempengaruhi motivasi belajar siswa (Anshari et al., 2017; Ariel \& Elishar-Malka, 2019; D. Siebert, 2019; Han \& Yi, 2019; Ruiz-Palmero et al., 2019; Seifert, 2014; Smith et al., 2018; Taalas et al., 2018), beberapa peneliti mengatakan bahwa kurangnya motivasi belajar dipengaruhi langsung oleh smartphone (Adiansha \& Sudirman, 2019; Alzubi et al., 2019; Luef et al., 2019). Situasi perilaku anak-anak yang sudah tercandu dengan smartphone secara langsung bisa mengganggu motivasi belajar dan membuat mereka sulit untuk berkonsentrasi dalam belajar. Hasil temuan lain menunjukkan bahwa realitas tersebut sudah menjadi masalah utama yang dapat mempengaruhi motivas belajar anak-anak. 
Smartphone yang awalnya dapat membantu peserta dididik kini membawa masalah bagi motivasi belajar mereka. Dengan demikian, terjadi kesenjangan antara perilaku penggunaan smartphone dengan motivasi belajar siswa terutama pada siswa SD di Kecamatan Bolo.

Oleh karena itu, sangatlah penting untuk membuat kajian dan penelitian dalam rangka mengetahui seberapa besar pengaruh penggunaan smartphone terhadap motivasi belajar siswa sekolah dasar. Penelitian ini sangat urgen demi memperbaiki motivasi belajar anak-anak SD yang saat ini mulai tidak fokus belajar dan justru hanya menghabiskan waktu mereka setiap hari dengan bermain smartphone baik di rumah maupun di sekolah. Berdasarkan latar belakang dan urgensi masalah tersebut, maka kami membuat rencana penelitian dengan judul "Pengaruh Penggunaan Smartphone Terhadap Motivasi Belajar Siswa Sekolah Dasar."

Adapun rumusan masalah dalam penelitian ini adalah "apakah ada pengaruh penggunaan smartphone terhadap motivasi belajar siswa Sekolah Dasar di Kecamatan Bolo?" Sedangkan tujuan dari penelitian ini adalah untuk menganalisis dan mengatahui seberapa besar pengaruh penggunaan smartphone terhadap motivasi belajar siswa-siswa Sekolah Dasar di Kecamatan Bolo.

\section{METODE}

Penelitian ini menggunakan pendekatan kuantitatif dengan menggunakan metode survei. Penelitian kuantitatif jenis survei merupakan penelitian kuantitatif yangmenggunakan kuesioner sebagai instrumen penelitian. Kuesioner merupakan lembaran yang berisikan daftar pertanyaan atau pernyataan dengan struktur yang ditentukan berdasarkan variabel-variabel yang ada. Populasi dalam penelitian ini adalah siswa-siswa SD yang ada di empat (4) SD di Kecamatan Bolo. Penelitian dilaksanakan hanya pada 4 SD karena keterbatasan waktu dan biaya. Sedangkan jumlah sampel yang digunakan adalah 84 siswa/i kelas V SD yang ada di empat sekolah dasar tersebut. Teknik pengumpulan data adalah lewat angket (kuisioner).

\section{HASIL DAN PEMBAHASAN Deskripsi Hasil Penelitian}

Deskripsi umum dari data hasil penelitian yang mencakup variabel-variabel penelitian dan hal ini sangat penting karena dasar dalam pembahasan dan penafsiran lebih lanjut. Penyajian data penelitian dari masing-masing variabel menggunakan program SPSS V. 26.0.

\section{Motivasi Belajar (Y)}

Jumlah angka skor untuk variabel motivasi belajar (Y) berada dalam rentang 48 hingga 114. Berdasarkan data yang diperoleh dalam penelitian kemudian diolah secara statistik dan diperoleh hasil, yakni jumlah keseluruhan ("Y) $=7.202$, nilai rata-rata atau mean sebesar 85,74 , dengan standar deviasi $(\mathrm{SDY})=14,46$, median 85 , modus 80 , skor minimum 48 , dan skor maksimumnya 114. Agar lebih jelas, maka dalam tabel berikut ini disajikan rekapitulasi angka-angka berdasarkan perhitungan statistik dasar. Uraian tersebut dapat direkapitulasi dalam tabel dibawah ini.

Tabel 1. Rekapitulasi Distribusi Hasil Perhitungan

\begin{tabular}{ccccccccc}
\hline $\begin{array}{c}\text { Variabel } \\
\text { Y }\end{array}$ & $n$ & $\sum Y$ & Mean & (SDY) & Median & Modus & $\begin{array}{c}\text { Skor } \\
\text { Terendah }\end{array}$ & $\begin{array}{c}\text { Skor } \\
\text { Tertinggi }\end{array}$ \\
\hline Skor & 84 & 7.202 & 85.74 & 14.46 & 85.5 & 80 & 48 & 114 \\
\hline
\end{tabular}

Selanjutnya, dari distribusi hasil tersebut dilakukan klasifikasi data dan frekuensinya dengan jumlah kelas 7 dan panjang kelas interval 10, seperti terlihat dalam tabel berikut: Tabel 2. Distribusi Frekuensi Skor Motivasi Belajar (Y)

\begin{tabular}{ccccc}
\hline No & Interval Kelas & $\begin{array}{c}\text { Frekuensi } \\
\text { Absolut }\end{array}$ & $\begin{array}{c}\text { Frekuensi } \\
\text { Relatif } \\
(\%)\end{array}$ & $\begin{array}{c}\text { Frekuensi } \\
\text { Komutatif } \\
(\%)\end{array}$ \\
\hline 1 & $48-57$ & 5 & 6 & 6 \\
\hline 2 & $58-67$ & 3 & 3.6 & 9.5 \\
\hline 3 & $68-77$ & 9 & 10.7 & 20.2 \\
\hline 4 & $78-87$ & 28 & 33.3 & 53.6 \\
\hline 5 & $88-97$ & 16 & 19 & 72.6 \\
\hline 6 & $98-107$ & 19 & 22.6 & 95.2 \\
\hline 7 & $108-117$ & 4 & 4.8 & 100 \\
\hline & Total & $\mathbf{8 4}$ & $\mathbf{1 0 0}$ & \\
\hline
\end{tabular}

Berdasarkan tabel distribusi frekuensi yang diklasifikasikan ini dapat diketahui bahwa dari jumlah 84 responden frekuensi terbanyak ada pada kelas interval 4 atau pada rentang nilai 78-87, dengan frekuensi absolut 28, frekuensi relatif 33,3\%, dan frekuensi kumulatifnya 53,6 $\%$. Sebaliknya frekuensi terendah terdapat 
pada kelas interval 2 atau pada rentang 58-67, dengan frekuensi absolut 3, dan frekuensi relatif $3,6 \%$, sedangkan frekuensi kumulatifnya adalah $9,7 \%$.

Berdasarkan data yang diperoleh dalam penelitian selanjutnya diolah secara statistik, dan diperoleh hasil, yakni jumlah keseluruhan ("X1) $=5.782$, nilai rata-rata (mean) sebesar 68.84 , dengan standar deviasi $(\mathrm{SDx} 1)=18.09$, median 65.50, modus 57, skor minimum 38, dan skor maksimumnya 106. Agar lebih jelas, maka dalam tabel berikut ini disajikan rekapitulasi angka-angka berdasarkan perhitungan statistik dasar.

\section{Smartphone (X1)}

Skor untuk variabel smartphone (X1) berada pada rentang 38 hingga 106.

Tabel 3. Rekapitulasi Distribusi Hasil Perhitungan

Variabel n $5 Y$ Mean (SDY) Median Modus Skor Skor
\begin{tabular}{ccccccccc}
$\mathrm{Y}$ & $\mathrm{n}$ & $\sum \mathrm{Y}$ & Mean & $(\mathrm{SDY})$ & Median & Modus & $\begin{array}{c}\text { Terendah } \\
\text { Tertinggi }\end{array}$ \\
\hline Skor & 84 & 5.78 & 68.84 & 18.09 & 65.50 & 57 & 36 & 106 \\
\hline
\end{tabular}

Selanjutnya, dari distribusi hasil tersebut dilakukan klasifikasi data dan frekuensinya dengan jumlah kelas 7 dan panjang kelas interval 10, seperti terlihat dalam tabel berikut:

Tabel 4. Distribusi Frekuensi Skor Smartphone (X1)

\begin{tabular}{ccccc}
\hline No & $\begin{array}{c}\text { Interval } \\
\text { Kelas }\end{array}$ & $\begin{array}{c}\text { Frekuensi } \\
\text { Absolut }\end{array}$ & $\begin{array}{c}\text { Frekuensi } \\
\text { Relatif } \\
(\%)\end{array}$ & $\begin{array}{c}\text { Frekuensi } \\
\text { Komutatif } \\
(\%)\end{array}$ \\
\hline 1 & $38-47$ & 10 & 11.9 & 11.9 \\
\hline 2 & $48-57$ & 15 & 17.9 & 29.8 \\
\hline 3 & $58-67$ & 50 & 23.8 & 53.6 \\
\hline 4 & $78-77$ & 14 & 16.7 & 70.2 \\
\hline 5 & $78-87$ & 9 & 10.7 & 81.0 \\
\hline 6 & $88-97$ & 8 & 9.5 & 90.5 \\
\hline 7 & $98-107$ & 8 & 9.5 & 100.0 \\
\hline \multicolumn{2}{c}{ Total } & $\mathbf{8 4}$ & $\mathbf{1 0 0}$ & \\
\hline
\end{tabular}

Berdasarkan tabel distribusi frekuensi skor smartphone (X1) dapat diketahui bahwa dari jumlah 84 responden frekuensi terbanyak ada pada kelas interval 3 dengan rentang nilai 5867 dengan frekuensi absolut 20, frekuensi relatif $23,8 \%$, sedangkan frekuensi kumulatifnya 53,6. Sebaliknya frekuensi terendah terdapat pada kelas interval 6 dan 7 bersama-sama memiliki frekuensi absolut 8 , frekuensi relatif $9,5 \%$.

\section{Pengujian Persyaratan Analisis Uji Normalitas}

Uji normalitas data penelitian dilakukan melalui uji Liliefors dengan nilai pada kolom
Kolmogorov-Smirnov. Untuk analisis pengujian menggunakan program SPSS V 26.0. Normal artinya jika nilai signifikansi lebih besar dari Alpha (á =0,05), sedangkan tidak, apabila nilai signifikansi lebih kecil dari nilai Alpha $(a ́=0,05)$. Dari hasil analisis program SPSS 25, dengan uji normalitas OneSample Kolmogorov-Smirnov Test pada data skor variabel motivasi belajar (Y), diperoleh nilai Asymp. Sig (2-tailed) $=0,065$. Hal ini menunjukkan bahwa nilai Asymp. Sig (2tailed) lebih besar dari harga Alpha (á) $=0,05$ atau 0,065 e" 0,05. Dengan demikian, Ha diterima, dan itu berarti data berdistribusi normal. Selanjutnya ujinormalitas variabel smartphone adalah diperoleh nilai Asymp. Sig (2-tailed) $=0,067$. Hal ini menunjukkan bahwa nilai Asymp. Sig (2-tailed) lebih besar dari harga Alpha (á) $=0,05$ atau 0,67 e" 0,05. Dengan demikian, Ha diterima, dan itu berarti data berdistribusi normal. Berikutnya adalah rangkuman hasil uji normalitas data dari ketiga variabel yakni X1 (skor smartphone)dan Y (skor motivasi belajar).

Tabel 5. Rangkuman Hasil Perhitungan Uji

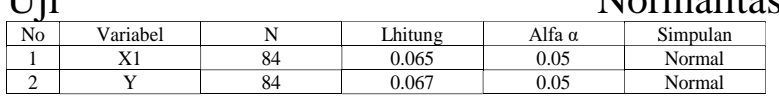

Berdasarkan hasil uji normalitas data yang telah dianalisis di atas ini maka dapat disimpulkan bahwa nilai signifikansi seluruh variabel lebih besar dari 0,05. Dengan demikian, data hasil penelitian yang berasaldari populasi secara analisis berdistribusi normal.

\section{Uji Linieritas}

Pengujian ini dilaksanakan dengan tujuan untuk mengukur apakah arah garis regresi variabel bebas (independen) terhadap variabel terikat (dependen) linier atau tidak.Uji linieritas dalam penelitian ini menggunakan metode Analysis of Variance (ANOVA), yaitu dengan melihat nilai Fhitungdeviasi dari linieritas. Sementara untukkriteria yang digunakan dalam uji linieritas adalah Alpha 5 $\%(0,05)$. Maka berarti Ho ditolak jika nilai probabilitas deviasi dari linieritas kurang (Sig d") atau sama dengan $(\mathrm{Sig}=)$ 0,05.

Berdasarkan hasil uji linieritas pada "ANOVA Table" diketahui bahwa nilai signifikansi pada liniearity variabel 
smartphone dengan variabel motivasi belajar siswa sebesar 0,015. Karena nilai signifikansi 0,015 d" dari á $=0,05$, maka dapat disimpulkan bahwa terdapat hubungan yang linier antara variabel smartphone (X1) dengan variabel motivasi belajar (Y). Dengan demikian, asumsi linieritas terpenuhi.

\section{Pengujian Hipotesis Penelitian}

Analisis Regresi PengaruhSmartphone (X1) terhadap Motivasi Belajar (Y)

Dalam praktik, analisis Regresi Sederhana (Simple Regression) digunakan untuk mengetahui sejauh mananilai hubungan atau pengaruh antara variabel independen atau bebas (X) dengan variabel dependen atau terikat (Y). Disebut regresi sederhana karena hanya ada satuvariabel independen (X). Pengujian dengananalisis regresi sederhana ditempuh dalambeberapa langkah seperti berikutTabel 6. Pengaruh Smartphone (x1) terhadap Motivasi belajar (Y)

\begin{tabular}{|c|c|c|c|c|c|c|}
\hline & \multirow{2}{*}{ Model } & \multicolumn{2}{|c|}{$\begin{array}{l}\text { Unstandardized } \\
\text { Coefficients }\end{array}$} & $\begin{array}{l}\text { Standardizer } \\
\text { Coefficients }\end{array}$ & \multirow[t]{2}{*}{$\mathrm{t}$} & \multirow{2}{*}{ Sig. } \\
\hline & & B & Std. Error & Beta & & \\
\hline & (Constant) & 72.569 & 6.099 & & 11.899 & $\begin{array}{c}0.00 \\
0\end{array}$ \\
\hline & Smartphone & 0.191 & 0.086 & 0.239 & 2.232 & $\begin{array}{c}0.02 \\
8\end{array}$ \\
\hline & Dependend Vari & Motiva & Belajar & & & \\
\hline
\end{tabular}

1) Persamaan Regresi Sederhana

Rumus yang dipakai untuk melihat persamaan regresi sederhana adalah $\mathrm{Y}=\mathrm{a}+$ bX1. Perhitungan analisis regresi terhadap data skor variabel motiavasi belajar atas variabel smartphone menghasilkan a (nilai konstanta) sebesar 72, 569 dan b (koefisien regresi) sebesar 0,191. Berdasarkan hasil tersebut maka pengaruh penggunaan smartphone (X1) terhadap motivasi belajar (Y) dapat dirumuskan menurut persamaan regresi, yakni: $\mathrm{Y}=72,569+0,191 \mathrm{X} 1$. Hasil $Y$ adalah 72,76. Dengan kata lain nilai 0,191 mengandung arti bahwa setiap penambahan $\mathrm{X}$ satuan (1\%) penggunaan smartphone (X), maka motivasi belajar Siswa (Y) akan meningkat sebesar 0,191.

2) Pengujian Hipotesis (Penentuan thitung dan t tabel)

Untuk pengujian hipotesis digunakan ttest. Uji t ini digunakan untuk mengetahui pengaruh yang signifikan antara variabel pengetahuan terhadap variabel keterlibatan. Berikut adalah cara dan ketentuan pengujiannya:
Pertama: Menghitung nilai t tabel:

a. Alfa (á) $/ 2=0,05 / 2=0,025$ (uji 2 sisi)

b. Degree of Freedom $(\mathrm{df})=($ jumlah data $84-1)=83$

c. Dengan ketentuan tersebut didapatnilai t tabel sebesar $(\mathrm{ttab})=1.989$

Kedua: Menentukan kriteriapengujian

a. Terima Ha jika $\mathrm{t}$ hitung (thitung) e"(ttabel) atau

b. Tolak Ho jika t hitung (thitung) d" (ttabel)

Ketiga: Membuat keputusan

Besarnya nilai t hitung (thit) adalah 2.232. Karena nilai t hitung antara X1 (smartphone) dengan Y (motivasi belajar) yang diperoleh lebih besar dari nilait tabel, yakni thitung = $2.232 \mathrm{e} "(\operatorname{ttab})=1.989$, maka Ho ditolak dan menerima Ha. Dengan demikian, dapat dinyatakan bahwa koefisien regresi adalah berarti. Artinya bahwa penggunaan smartphone berpengaruh terhadap motiivasi belajar siswa.

Tingkat signifikansi pengaruh antara variabel penggunaan smartphone dengan motivasi belajar siswa dapat dilihat pada tabel berikut:

Tabel 7. Anova ${ }^{a}$

\begin{tabular}{|c|c|c|c|c|c|}
\hline Model & $\begin{array}{c}\text { Sum of } \\
\text { Squares }\end{array}$ & df & $\begin{array}{c}\text { Mean } \\
\text { Square }\end{array}$ & F & Sig. \\
\hline Regression & 993.791 & 1 & 993.791 & 4.981 & $.028^{\mathrm{b}}$ \\
Residual & 16360.447 & 82 & 199.518 & & \\
Total & 17354.238 & 83 & & & \\
\hline $\begin{array}{l}\text { a. Dependend Variable: Motivasi_Belajar } \\
\text { b. Predictors: (Constant), Smartphone }\end{array}$ & & & \\
\hline
\end{tabular}

Apabila dianalisis dari segi pengujian berdasarkan signifikansi maka kriteriahi potesisnya adalah:

Ha diterima jika signifikansi e" 0,05

Ho ditolak jika signifikansi d" 0,05

Dari uji Anova dihasilkan untuk nilai Fhitung adalah 4.981 dengan tingkat signifikansi (angka probabilitas) sebesar 0,028. Karena angka probabilitas (Sig.) jauh lebih kecil dari alfa (á): Sig. $=0,028$ d" dari á $=0,05$, maka Ho ditolak dan Ha diterima. Artinya ada pengaruh antara penggunaan smartphone (X1) dengan motivasi belajar siswa (Y).

3) Analisis Koefisien Determinasi (RSquare)

Analisis determinasi digunakan untuk mengetahui prosentase sumbangan pengaruh variabel smartphone terhadap variabel motivasi belajar. Hasil analisis determinasi dapat dilihat pada output SPSS 
V. 26.0. Model Summary dari hasil analisis regresi linier sederhana di bawah ini

Tabel 8. Model Summary ${ }^{\mathrm{b}}$

\begin{tabular}{|l|c|c|c|c|}
\hline Model & $\mathrm{R}$ & $\mathrm{R}$ Square & Adjusted R Square & $\begin{array}{c}\text { Std. Error of the } \\
\text { Estimate }\end{array}$ \\
\hline 1 & $0.239^{\mathrm{a}}$ & 0.057 & 0.046 & 14.12507 \\
\hline $\begin{array}{l}\text { a. Predictors: (Constant), Smartphone } \\
\text { b. Dependent Variabel: Motivasi_Belajar }\end{array}$ \\
r
\end{tabular}

\section{PEMBAHASAN}

Berdasarkan hasil uji hipotesis di atas maka dapat dibuktikan bahwa ada pengaruh variabel penggunaan smartphone terhadap motivasi belajar siswa SD di Kecamatan Bolo. Hal ini dapat dibuktikan dari hasil uji t yakni thitung 2.232 lebih besar dari tabel 1.989 dengan tingkat signifikansi 0.028. Artinya terdapat pengaruh penggunaan smartphone terhadap motivasi belajar siswa SD. Selanjutnya bila dikaji dari hasil tabe lModel Summary pada pengujian R Square mendapat nilai koefisien determinasi sebesar 0,057 atau $5.7 \%$. Hal ini berarti bahwa variabel penggunaan smartphone (X1) memiliki pengaruh kontribusi terhadap motivasi belajar siswa (Y) sebesar 5,7\% dan 94,3\% lainnya dipengaruhi oleh variabel lain di luar variabel penggunaan smartphone. Hal ini mau menunjukkan bahwa smartphone dapat mempengaruhi motivasi belajar siswa. Pembelajaran digital yang menggunakan smartphone dengan baik bisa meningkatkan motivasi belajar siswa. Hal ini nampak jelas pada penelitian dari Syamsudin (2018) yang menemukan bahwa penggunaan aplikasi tajwid berbasis smartphone lebih baik hasilnya dari pada pembelajaran konvensional, bahkan penggunaan aplikasi tajwid berbasis smartphone berpengaruhsignifikan terhadap peningkatan prestasi belajar siswa.

Smartphone bisa meningkatkan motivasi belajar siswa apabila digunakan sebagai media pembelajaran digital. Ming Hun Lin, dkk (2017) menegaskan bahwa pembelajaran digital memberikan pengaruhyang positif terhadap motivasi belajar siswa dan juga dapat meningkatkan hasil belajar siswa SD. Dalam teori motivasi dan pembagiannya, penggunaan smartphone menjadi salah satu contoh motivasi ekstrinsik di mana hal atau keadaaan yang datang dari luar individu siswa yang mendorongnya untuk melakukan kegiatan belajar. Penggunaan smartphone termasuk faktor dari luar siswa SD yang mempengaruhi motivasi belajar mereka. Smartphone termasuk faktor dari luar siswa SD yang mempengaruhi motivasi belajar mereka. Ketergantungan siswa pada smartphone secara langsung membuat mereka malas belajar. Pada dasarnya belajar sangat diperlukan adanya motivasi. Sedangkan motivasi yang kurang akan mengakibatkan siswa menjadi tidak tertarik untuk belajar. Siswa menjadi bosan, sehingga malas untuk mengejarkan tugas yang diberikan guru. Dengan kata lain, hasil belajar akan lebih optimal, jika ada motivasi. Ada begitu banyak alasan mengapa siswa merasa lebih termotivasi ketika siswa menggunakan smartphone dalam pembelajaran. Liu (2016) dalam penelitiannya kepada 31 guru di sekolah dasar dalam pembelajaran di kelas menunjukkan 31,1\% mereka menjawab alasan mereka menggunakan teknologi dalam pembelajaran adalah untuk membantu keterlibatan dan motivasi belajarsiswa SD di kelas (Francis, 2017). Thomas, O'Bannon dan Bolton (2013) dalam penelitian mereka menemukan bahwa ponsel dapat meningkatkan pembelajaran siswa. Mereka menemukan bahwa $59 \%$ ponsel dapat membantu meningkatkan keterlibatan dan motivasi belajar siswa.

Hasil penelitian ini sejalan dengan hasil penelitian yang teliti oleh Gardenia Augusta (2018) yang menegaskan bahwa penggunaan smartphone pada mahasiswa memiliki pengaruh terhadap motivasi belajar mereka sebesar $4.3 \%$ dan sisanya 95.7 dipengaruhi variabel lain dengantingkat signifikansi sebesar 0,037. Menurut Augusta mahasiswa dewasa ini cenderung selalu menggunakan smartphone mereka dibandingkan membaca buku. Smartphonehanya digunakan sebatas browser data, internet, dan game. Realitas ini serupa dengan hasil penelitian Satriawanati (2017) anak menjadi terabaikan lewat kasih sayang palsu yang diberikan orangtua dengan cara memberikan dan menyediakan fasilitas kepada anak mereka berupa smartphone, bermain game, menonton TV secara berlebihan. Hal ini membuat anak menjadi malas belajar, lebih menyukai yang instan 
bahkan bisa membuat hasil belajar menjaid rendah.

Beberapa uraian tersebut sesuai dengan hasil penelitian di mana pengaruh penggunaan smartphone terhadap motivasi belajar siswa SD di Kecamatan Bolo masuk dalam kategorir endah yakni hanya $5.7 \%$. Artinya variabel penggunaan smartphone bukan faktor dominan dan utama untuk meningkatan motivasi belajar siswa di tingkat sekolah dasar. Berdasarkan angket yang disebarkan nampak jelas bahwa siswa SD di Kecamatan Bolo memiliki martphone hanya dalam konteks bisa berkomunikasi dengan mudah, sarana hiburan, bermain game, media sosial dan internet. Siswa yang terlalu banyak menggunakan smartphone menyebabkan penurunan motivasi belajar baik di sekolah maupun di rumah. Siswa lebih asyik memainkan smartphone pada hal-hal hiburan dangan dibandingkan penggunaannya pada konteks pembelajaran atau sumber belajar.

\section{KESIMPULAN}

Berdasarkan hasil analisis yang telah diuraikan, maka penelitian ini menghasilkan kesimpulan sebagai berikut: Penggunaan smartphone memiliki pengaruh terhadap motivasi belajar siswa SD yang ada di Kecamatan Bolo meskipun tingkat pengaruhnya masih tergolong rendah yakni $5.7 \%$ dengan tingkat signifikansi 0,028. Begitupun dengan hasil pengujian $t$ tabel lebih besar dari pada t hitung yakni thitung $=2.232$ e" $($ ttab $)=1.989$, maka Ho ditolak dan menerima Ha. Dengan demikian, dapat dinyatakan bahwa koefisien regresi adalah berarti. Artinya bahwa penggunaan smartphone berpengaruh terhadap motivasi belajar siswa.

Adapun saran yang dapat direkomendasikan adalah: (1) Bagi Siswa: Siswa SD mulai belajar membatasi penggunaan smartphone yang berlebihan namun lebih fokus penggunaan smartphone pada aspek membantu proses pembelajaran seperti mencari tugas, informasi dan sumber pembelajaran dirumah; (2) Bagi Guru: Para guru perlu memperhatikan siswa untuk melarang keras penggunaan smartphone di lingkungan sekolah. Guru secara berlahanlahan memberi pengarahan cara menggunakan smartphone dalam konteks mencari materi pembelajaran dan media pembelajaran baik di sekolah maupun di rumah. (3) Bagi orang tua: Orang tua di rumah perlu mengontrol anaknya di rumah untuk tidak selalu bermain smartphone apalagi tidak ada hubungannya dengan proses pembelajaran. Kelebihan menggunakan smartphone bagi anak-anak akan menurunkan semangat belajar mereka dirumah.

\section{DAFTAR PUSTAKA}

Adiansha, A. A., \& Sudirman, I. K. (2019). Hubungan Budaya Organisasi dan Kinerja Dosen dalam Motivasi Mahasiswa di STKIP Taman Siswa Bima. JURNAL PENDIDIKAN MIPA, 9(2), 97-100. https://doi.org/https://doi.org/10.376 30/jpm.v9i2.210

Alzubi, A. A. F., Singh, M. K. A. P. M., \& Hazaea, A. N. (2019). Investigating reading learning strategies through smartphones on Saudi learners' psychological autonomy in reading context. International Journal of Instruction, 12(2), 99-114. https://doi.org/10.29333/iji.2019.122 $7 \mathrm{a}$

Anshari, M., Almunawar, M. N., Shahrill, M., Wicaksono, D. K., \& Huda, M. (2017). Smartphones usage in the classrooms: Learning aid or interference? Education and Information Technologies, 22(6), 3063-3079. https://doi.org/10.1007/s10639-0179572-7

Ariel, Y., \& Elishar-Malka, V. (2019). Learning in the smartphone era: Viewpoints and perceptions on both sides of the lectern. Education and Information Technologies, 24(4), 2329-2340.

https://doi.org/10.1007/s10639-01909871-w

Ataş, A. H., \& Çelik, B. (2019). Smartphone Use of University Students: Patterns, 
Purposes, and Situations. Malaysian Online Journal of Educational Technology, 7(2), 54-70. https://doi.org/10.17220/mojet.2019. 02.004

Bağc1, H., \& Pekşen, M. F. (2018). Investigating The Smart Phone Addictions Of Vocational School Students From Different Variables. Malaysian Online Journal of Educational Technology, 6(4), 40-52. https://doi.org/10.17220/mojet.2018. 04.004

Criollo, S. C., \& Luján-Mora, S. (2018). A SWOT analysis of bring your own devices in mobile learning. Proceedings of the 14th International Conference on Mobile Learning 2018, ML 2018, 148-152.

D. Siebert, M. (2019). The Silent Classroom: The Impact of Smartphones and a Social Studies Teacher's Response. The Social Studies, 110(3), 122-130. https://doi.org/10.1080/00377996.20 19.1580666

Daltio, E., Gama, J., França, G., Prata, D., \& Veloso, G. (2018). The potential use of smartphone and social networks in public schools: A case study in north of Brazil. Proceedings of the 14th International Conference on Mobile Learning 2018, ML 2018, 39-46.

Han, S., \& Yi, Y. J. (2019). How does the smartphone usage of college students affect academic performance? Journal of Computer Assisted Learning, 35(1), 13-22. https://doi.org/10.1111/jcal.12306

Luef, E. M., Ghebru, B., \& Ilon, L. (2019). Language Proficiency and Smartphone-Aided Second Language Learning: A Look at English, German, Swahili, Hausa and Zulu. Electronic Journal of E-Learning, 17(1), 25-37.

Migdalski, S. T. (2017). Smartphone and Curriculum Opportunities for College Faculty. Journal of Learning in Higher Education, 13(2), 59-64.

Nicolaou, C., Matsiola, M., \& Kalliris, G.
(2019). Technology-enhanced learning and teaching methodologies through audiovisual media. Education Sciences, 9(3). https://doi.org/10.3390/educsci90301 96

Nyasulu, C., \& Dominic Chawinga, W. (2019). Using the decomposed theory of planned behaviour to understand university students' adoption of WhatsApp in learning. E-Learning and Digital Media, 16(5), 413-429. https://doi.org/10.1177/20427530198 35906

Pedrero-Esteban, L. M., Barrios-Rubio, A., \& Medina-ávila, V. (2019). Teenagers, smartphones and digital audio consumption in the age of Spotify. Comunicar, 27(60), 103-112. https://doi.org/10.3916/C60-2019-10

Ruiz-Palmero, J., Vega, E. S., Sánchez-Rivas, E., \& Gómez-García, M. (2019). Future teachers' smartphone uses and dependence. Education Sciences, 9(3), 1-11. https://doi.org/10.3390/educsci90301 94

Seifert, T. (2014). Pedagogical applications of smartphone integration in teaching Lecturers', students' \& pupils' perspectives. Proceedings of the 10th International Conference on Mobile Learning 2014, ML 2014, 117-124.

Smith, H. E., Blackburn, J. J., Stair, K., \& Burnett, M. (2018). Assessing the Effects of the Smartphone as a Learning Tool on the Academic Achievement of School-Based Agricultural Education Students in Louisiana. Journal of Agricultural Education, 59(4), 270-285. https://doi.org/10.5032/jae.2018.042 70

Susilawati, Y., \& Adiansha, A. A. (2018). Hubungan Kepribadian dan Efikasi Diri Dengan Motivasi Belajar Siswa Kelas IV Sekolah Dasar. 8(2), 142151.

Taalas, P., Jalkanen, J., Bradley, L., Thouësny, S., \& Kennedy, O. (2018). Examining 
Terakreditasi Peringkat 4 (No. SK: 36/E/KPT/2019)

student perceptions about smartphones to understand lack of acceptance of mobile-assisted language learning. Future-Proof CALL: Language Learning as Exploration and Encounters - Short Papers from EUROCALL 2018, 137141.

https://doi.org/10.14705/rpnet.2018.2 6.826

Yildiz, E. P., \& Alkan, A. (2019). Investigation of Vocational High School Students \&\#39;Views on Smart Phone Use: A Case Study. Higher Education Studies, $9(3), \quad 45$. https://doi.org/10.5539/hes.v9n3p45 